\title{
Influence of Inorganic Ions and Organic Substances on the Degradation of Pharmaceutical Compound in Water Matrix
}

\author{
Edyta Kudlek*, Mariusz Dudziak and Jolanta Bohdziewicz \\ Faculty of Energy and Environmental Engineering, Silesian University of Technology, Konarskiego 18, \\ 44-100 Gliwice, Poland; mariusz.dudziak@polsl.pl (M.D.); jolanta.bohdziewicz@polsl.pl (J.B.) \\ * Correspondence: edyta.kudlek@polsl.pl; Tel.: +48-322-372-478
}

Academic Editor: Fabio Masi

Received: 18 September 2016; Accepted: 8 November 2016; Published: 15 November 2016

\begin{abstract}
The paper determined the influence of inorganic substances and high-molecular organic compounds on the decomposition of diclofenac, ibuprofen, and carbamazepine in the process of photocatalysis conducted with the presence of Titanium dioxide $\left(\mathrm{TiO}_{2}\right)$. It was determined that the presence of such ions as $\mathrm{CO}_{3}^{2-}, \mathrm{HCO}_{3}^{-}, \mathrm{HPO}_{4}^{2-}$ as well as $\mathrm{SO}_{4}^{2-}$ inhibited the decomposition of carbamazepine, whereas the efficiency of diclofenac degradation was decreased only by the presence of $\mathrm{CO}_{3}^{2-}$ and $\mathrm{HCO}_{3}^{-}$anions. In case of ibuprofen sodium salt (IBU), all investigated anions influenced the increase in its decomposition rate. The process of pharmaceutical photooxidation conducted in suspensions with $\mathrm{Al}^{3+}$ and $\mathrm{Fe}^{3+}$ cations was characterized by a significantly decreased efficiency when compared to the solution deprived of inorganic compounds. The addition of $\mathrm{Ca}^{2+}, \mathrm{Mg}^{2+}$ and $\mathrm{NH}_{4}{ }^{+}$ affected the increase of reaction rate constant value of diclofenac and ibuprofen decomposition. On the other hand, high molecular organic compounds present in the model effluent additionally catalysed the degradation process of pharmaceutical compounds and constituted an additional sorbent that enabled to decrease their concentration. Toxicological analysis conducted in deionized water with pharmaceutical compounds' patterns proved the production of by-products from oxidation and/or reduction of micropollutants, which was not observed for model effluent irradiation.
\end{abstract}

Keywords: pharmaceuticals; photocatalysis; cations and anions; organic compounds; toxicological assessment

\section{Introduction}

Pharmaceutical compounds constitute one of the largest groups among organic micropollutants that are present in the aquatic environment [1]. Municipal effluents into which these compounds are transported along with waste products from people taking them, inappropriately utilized expired or unused medication a well as surface effluents from farming areas on which they were applied are considered their main source [2,3]. It is estimated that the pharmaceutical market of the European Union comprises approximately 3000 different substances [4], and this number keeps increasing. Wastewater treatment plants that apply conventional wastewater treatment methods based mainly on activated sludge methods that enable to decrease the concentration of high molecular organic compounds and biogenic compounds do not guarantee a complete elimination of pharmaceutical micropollutants [5] classified as hardly biodegradable substances [6].

One of the methods that guarantees high removal rates of organic substances including pharmaceutical compounds [7-9] is the process of heterogenic photocatalysis conducted with the application of catalysts of a different type; out of them nanomolecules of Titanium dioxide $\left(\mathrm{TiO}_{2}\right)$ are described in the literature most frequently [10]. 
The mechanism of reactions occurring on the surface of a catalyst during the process of photochemical oxidation is divided on five stages, i.e., photoexcitation, diffusion, trapping, recombination, and oxidation [11]. The course of these stages involve the oxidation and reduction of compounds adsorbed in active centres of semiconductors by means of highly reactive free hydroxyl radicals $\mathrm{OH}^{\bullet}$. The process of micropollutants adsorption may be hindered by the presence of organic or inorganic compounds that block active centres on the catalyst surface. Chládková et al. [12] indicated that common inorganic anions $\mathrm{Cl}^{-}, \mathrm{NO}_{3}^{-}$and $\mathrm{SO}_{4}^{2-}$ can be competitively adsorbed on the surface of the photocatalyst and decrease the photodegradation rate of organic caompunds. On the other hand, some inorganic compounds such as sulfate ions can be immobilized on the surface of $\mathrm{TiO}_{2}$ nanoparticles and improve the photocatalytic activity of the formed composite [13].

Pharmaceuticals which are biologically active compounds-apart from their therapeutic effect-may also demonstrate a toxic character against aquatic organisms; therefore, in case of water streams' treatment there exists the need for a comprehensive assessment of the removal rate of micropollutants by the application of analytical methods that enable to explicitly identify pharmaceuticals and products formed during their natural or assisted decomposition. Additionally, there exists the necessity for a toxicological analysis of the formed decomposition by-products. In this case, the widespread use of biotests conducted on a variety of indicator organisms, i.e., on bacteria, crustacea, fresh- and saltwater fish as well as on vascular plants [14-17]. Special attention should be paid to tests conducted on bioluminescent organisms that prove sensitivity towards a wide range of toxicants including pharmaceutical compounds [18] that enable to obtain results in a very short period of time [19].

This paper describes the efficiency of removal of three medications most frequently identified in the aquatic environment, i.e., diclofenac, ibuprofen, and carbamazepine, from water suspensions in the process of heterogenic photocatalysis with the presence of selected inorganic compounds and organic substances. The process of photochemical oxidation and reduction was conducted in the presence of $\mathrm{TiO}_{2}$ as a catalyst of this process. The kinetics of the process was described by means of Langmuir-Hisherwood equation. The efficiency of the process was also assessed on the basis of the decrease in concentration of pharmaceutical micropollutants as well as toxicological measurements of the subprocess suspensions with the use of bioluminescence bacteria Aliivibrio fischeri (Microtox ${ }^{\circledR}$ test). It enabled to comprehensively assess the degree of pollutants mineralization process as well as to establish potential toxicity against living organisms that may prove generation of by-products of oxidation process of pharmaceuticals.

\section{Materials and Methods}

\subsection{Materials and Reagents}

Patterns of pharmaceutical micropollutants used during the research were from the group of nonsteroidal anti-inflammatory analgesics supplied as diclofenac sodium salt (DCF) and ibuprofen sodium salt (IBU) as well as a psychoactive drug-carbamazepine (CBZ) from Sigma-Aldrich (Poznań, Poland) (Table 1). Their percentage of purity exceeded $98 \% . \mathrm{TiO}_{2}$ applied as a catalyst into the process of heterogenic photocatalysis was purchased from Evonik Degussa GmbH (Hanau, Germany) and labelled by the manufacturer with the symbol of P25. Additionally, methanol and acetonitryle by Avantor Performance Materials Poland S.A. (Gliwice, Poland) was used in this research. 
Table 1. Characteristics of tested pharmaceutical compounds.

\begin{tabular}{|c|c|c|c|}
\hline Pharmaceutical Compound & Diclofenak Sodium Salt & Ibuprofen Sodium Salt & Carbamazepine \\
\hline \multicolumn{4}{|l|}{ Structural formula } \\
\hline $\begin{array}{l}\text { Molecular formula } \\
\text { CAS No. }\end{array}$ & $\begin{array}{c}\mathrm{C}_{14} \mathrm{H}_{10} \mathrm{Cl}_{2} \mathrm{NNaO}_{2} \\
15307-79-6\end{array}$ & $\begin{array}{l}\mathrm{C}_{13} \mathrm{H}_{17} \mathrm{NaO}_{2} \\
31121-93-4\end{array}$ & $\mathrm{C}_{16} \mathrm{H}_{12} \mathrm{~N}_{2} \mathrm{O}$ \\
\hline Molecular weight, $\mathrm{g} / \mathrm{mol}$ & 318.13 & $\begin{array}{c}31121-93-4 \\
228.26\end{array}$ & $\begin{array}{c}298-46-4 \\
236.30\end{array}$ \\
\hline Solubility in water, $\mathrm{mg} / \mathrm{L}$ & 50 & 100 & 17 \\
\hline $\mathrm{pK}_{\mathrm{a}}$ & 4.15 & 4.91 & 2.30 \\
\hline
\end{tabular}

\subsection{Study Subject}

Water solutions with the addition of pharmaceutical compounds of the concentration of $1 \mathrm{mg} / \mathrm{L}$ constituted the subject of the study. High concentrations of DCF, IBU and CBZ that exceeded the usual environmental concentrations were applied due to the increase of accuracy of the conducted analytical measurements. The influence of inorganic ions on the efficiency of oxidation and reduction of micropollutants was determined by the addition of $1 \mathrm{~mol} / \mathrm{L}$ inorganic salts, i.e., $\mathrm{NaCl}, \mathrm{Na}_{2} \mathrm{CO}_{3}$, $\mathrm{NaHCO}_{3}, \mathrm{Na}_{2} \mathrm{SO}_{4}, \mathrm{Na}_{2} \mathrm{HPO}_{4}$ and $\mathrm{AlCl}_{3}, \mathrm{FeCl}_{3}, \mathrm{CaCl}_{2}, \mathrm{MgCl}_{2}, \mathrm{NH}_{4} \mathrm{Cl}$ to the water solutions. In order to determine the influence of organic substances on the degradation of pharmaceutical micropollutants, the process was conducted with the use of synthetic effluent after mechanical and biological treatment conducted on conventional wastewater treatment plant (WWTP) with the addition of pharmaceuticals patterns. The solution was prepared by adding $152 \mathrm{mg}$ of dry stock and $226 \mathrm{mg}$ of casein peptone to $1 \mathrm{~L}$ of tap-water. The mixture was heated to reach $100{ }^{\circ} \mathrm{C}$, and after cooling it down to $21 \pm 2{ }^{\circ} \mathrm{C}$ the inorganic compounds were introduced, i.e., $\mathrm{NH}_{4} \mathrm{Cl}(20 \mathrm{mg} / \mathrm{L}), \mathrm{NaCl}(7 \mathrm{mg} / \mathrm{L}), \mathrm{CaCl}_{2} \cdot 6 \mathrm{H}_{2} \mathrm{O}$ $(7.5 \mathrm{mg} / \mathrm{L}), \mathrm{MgSO}_{4} \cdot 7 \mathrm{H}_{2} \mathrm{O}(2 \mathrm{mg} / \mathrm{L}), \mathrm{K}_{2} \mathrm{HPO}_{4}(40 \mathrm{mg} / \mathrm{L}), \mathrm{KH}_{2} \mathrm{PO}_{4}(16 \mathrm{mg} / \mathrm{L})$. The prepared mixture was diluted 10 times. The physical and chemical characteristics of the obtained solution are presented in Table 2.

Table 2. Characteristics of the water matrix.

\begin{tabular}{cc}
\hline Indicators of Pollution & Model Effluent \\
\hline $\mathrm{pH}$ & 7.10 \\
Conductivity, $\mu \mathrm{S} / \mathrm{cm}$ & 772.12 \\
UV-VIS absorbance $(\lambda=254 \mathrm{~nm}), \mathrm{cm}^{-1}$ & 0.063 \\
$\mathrm{ChZT}_{\mathrm{mg} \mathrm{O}} / \mathrm{L}$ & 32.21 \\
$\mathrm{BOD}_{5}, \mathrm{mg} \mathrm{O}_{2} / \mathrm{L}$ & 5.23 \\
$\mathrm{~N}_{\mathrm{NH}}, \mathrm{mg} / \mathrm{L}$ & 1.58 \\
$\mathrm{~N}_{4} \mathrm{NO}_{3}, \mathrm{mg} / \mathrm{L}$ & 3.50 \\
$\mathrm{P}_{\mathrm{PO}}, \mathrm{mg} / \mathrm{L}$ & 6.60 \\
$\mathrm{TOC}_{\mathrm{mg}} / \mathrm{L}$ & 0.40 \\
$\mathrm{IC}^{\mathrm{mg}} / \mathrm{dm}$ & 21.38 \\
Total organich & 50.54 \\
\hline
\end{tabular}

\subsection{Photocatalysis Process}

The process of heterogenic photocatalysis was conducted in a laboratory glass sequential batch reactor with a volume of $700 \mathrm{~mL}$ by Heraeus (Hanau, Germany) (Figure 1) equipped with a medium-pressure mercury vapour UV lamp $(150 \mathrm{~W})$ placed in a cooling jacket. The cooling process of the lamp was performed by means of tap water and enabled to keep a constant temperature of the conducted process that did not exceed $20 \pm 1{ }^{\circ} \mathrm{C}$. The UV lamp emanated radiation with a wavelength $\lambda_{\text {exc }}$ equal to $313,365,405,436,546$ and $578 \mathrm{~nm}$. Thus, the water suspensions were irradiated with UV-A and visible light. The dose of catalyst applied to the reaction mixture reached the level of $50 \mathrm{mg} / \mathrm{L}$, whereas the time of contact of the catalyst with the mixture before UV irradiation process (dark mixing 
inside the reactor) was set to $15 \mathrm{~min}$. This step ensured the adsorption of micropollutants on the surface of $\mathrm{TiO}_{2}$, what constitutes the basis for a proper run of photocatalytic oxidation and/or reduction of pharmaceuticals. To ensure proper mixing of the reactor content during the process and to avoid catalyst sedimentation, the reactor was placed on a magnetic stirrer.

The UV lamp was placed into the reactor after she obtained a stable intensity of irradiation $(90 \mathrm{~s}$ after the UV lamp was light up). On the other hand, an aeration pump of capacity of $4 \mathrm{~L}$ air per minute was applied to oxidate the system. The separation of catalyst from the post-reaction mixture was conducted through the process of microfiltration with the application of a filtration set equipped with membrane filters of 0.45 membrane pore sizes by Merck Milipore (Darmstadt, Germany), with vacuum pump by AGA Labor (Warsaw, Poland).

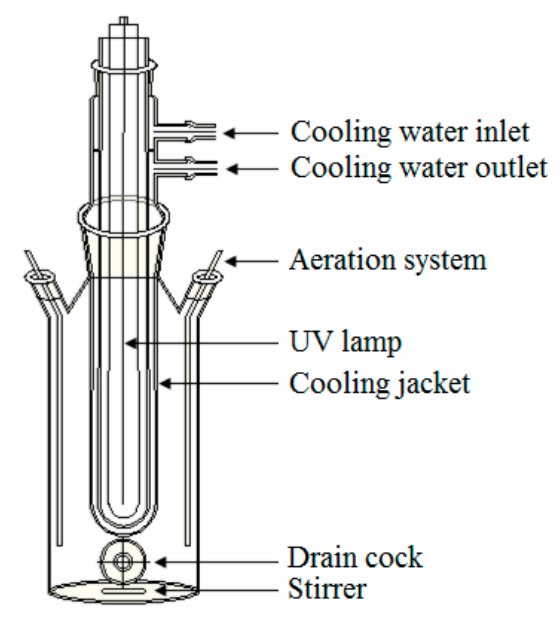

Figure 1. Scheme of the photocatalytic batch reactor.

The kinetics of the photocatalysis process was calculated with the Langmuir-Hinsherwood equation, as a correlation between the concentration of the pharmaceutical micropollutant in the investigated solutions and the time devoted to the UV irradiation (Equation (1)):

$$
r=\frac{d C}{d t}=k\left(\frac{K C}{1+K C}\right)
$$

With the assumption that the degradation process of the pharmaceutical compound becomes a pseudo-first order reaction, the reaction rate constant may be established as a linear regression slope (Equation (2)):

$$
\ln \left(\frac{C_{t}}{C_{0}}\right)=-k t
$$

where: $k$ constitutes the reaction rate constant of the pharmaceutical compound degradation $\left(\mathrm{min}^{-1}\right)$, $K$ is an equilibrium constant of the drug adsorption on the catalyst surface, whereas $C_{0}, C_{t}$ is the drug concentration in the water matrix before the commencement of the irradiation process $(t=0)$ and after a given time indicated as $t$.

The awareness of a reaction rate constant $k$ enables to identify the half life $t_{\frac{1}{2}}$ on the basis of the Equation (3):

$$
t_{\frac{1}{2}}=\frac{\ln 2}{k}
$$

\subsection{Analytical Procedure}

To facilitate chromatographic identification of analytes out of the water samples with a volume of $20 \mathrm{~mL}(\mathrm{pH}=7)$ the investigated pharmaceuticals were separated with the solid phase extraction (SPE) 
in a single-use columns Supelclean ${ }^{\mathrm{TM}}$ ENVI-8 volume $6 \mathrm{~mL}(1.0 \mathrm{~g})$ by Supelco (Poznań, Poland) filled with octylsilyl bad $\left(\mathrm{C}_{8}\right)$. Before the extraction stage the bad was rinsed with $5 \mathrm{~mL}$ of methanol and conditioned with $5 \mathrm{~mL}$ of deionised water with $\mathrm{pH}=7$. Then, the water sample was applied onto the extraction column with a constant flow at the level reaching $1 \mathrm{~mL} / \mathrm{min}$. After the extraction the column bad was dried for $5 \mathrm{~min}$ at vacuum. The extract was eluted with $3 \mathrm{~mL}$ of methanol and then dried in a nitrogen stream. High-performance liquid chromatography HPLC equipped with UV-VIS detector by Varian (Warsaw, Poland) was incorporated for micropollutant determination. The identifications of the analytes were conducted by the use of Hypersil GOLD column by Thermo Scientific (Warsaw, Poland) of length equal to $25 \mathrm{~cm}$, diameter of $4.6 \mathrm{~mm}$ and granulation of $5 \mu \mathrm{m}$. Detector wavelength $(\lambda)$ necessary to obtain the required sensitivity was established at $220 \mathrm{~nm}$. The mobile phase consisted of a mixture of acetonitryl and water in the ratio 85:15 $(v / v)$, in which the flow rate reached $1 \mathrm{~mL} / \mathrm{min}$. Sample injections were performed manually with a micro-syringe of $50 \mu \mathrm{L}$ by Hamilton.

Degradation by-products of the tested pharmaceutical compounds, generated during photocatalysis ware estimated using Saturn $2100 \mathrm{~T}$ gas chromatograph (GC) coupled with mass spectrometer (MS) of ion trap type with electron ionization (EI) by Varian (Warsaw, Poland). Chromatograph was equipped with $30 \mathrm{~m} \times 0.25 \mathrm{~mm} \mathrm{SLB}{ }^{\mathrm{TM}}-5 \mathrm{~ms}$ capillary column of $0.25 \mu \mathrm{m}$ film thickness by Supelco (Poznan, Poland). Helium 5.0 was used as the carrier gas. The temperature of ion trap and ion source was $180^{\circ} \mathrm{C}$.

\subsection{Toxic Bioassay}

Toxicological assessment of the process was performed with Microtox ${ }^{\circledR}$ biotest that incorporates bioluminescent bacteria Aliivibrio fischeri as bioindicators. The test was carried out according to the Screening Test procedure by MicrotoxOmni system in the Microtox analyser Model 500 by Modern Water (Warsaw, Poland). The bacterial species Aliivibrio fischeri demonstrate high sensitivity across a wide variety of organic and inorganic toxic substances [20]. The test result was presented by a percentage of bioluminescence inhibition which is a result of inhibition of metabolic processes of bioindicators when exposed to a toxic substance for 15-min in reference to a control sample test constituting $2 \% \mathrm{NaCl}$ solution.

\section{Results and Discussion}

\subsection{Influence of Inorganic Anions}

Figure 2 presents the rates of concentration decrease of pharmaceuticals present in deionized water suspensions with selected anions added as sodium salts. The preliminary investigations were conducted to assess the adsorption process of the investigated pharmaceutical compounds on the photocatalyst particles for the contact time equal to $15 \mathrm{~min}$. This step initiated the placement of micropollutants around active centres of semiconductor which were supposed to accelerate their degradation after the implementation of UV irradiation process. The absorption of pharmaceutical compounds on the photocatalyst surface depends on the chemical structure of the compound and the type of semiconductor [21]. The 19\% decrease of DCF concentration, 37\% IBU and $12 \%$ CBZ was observed for $\mathrm{P} 25 \mathrm{TiO}_{2}$. It is necessary to highlight the fact that the process was conducted in suspensions with $\mathrm{pH} 7$, so being around the $\mathrm{pH}$ value of isoelectric point of the type of $\mathrm{TiO}_{2}$ used in this study [22,23]. In these conditions, the surface of semiconductor particles has a neutral charge. Therefore, the phenomenon of adsorption of pharmaceutical substances with a negative electrostatic charge is intensified and at the same time it increases the level of their elimination. Thus, it may be assumed that the higher degree of adsorption of IBU being a weak acid was a result of the mutual attraction between the surface of the catalyst and the negatively charged pharmaceutical particles. 


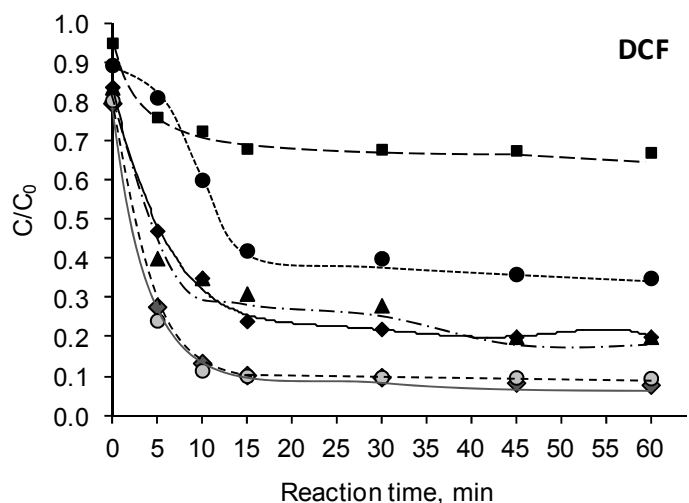

(a)

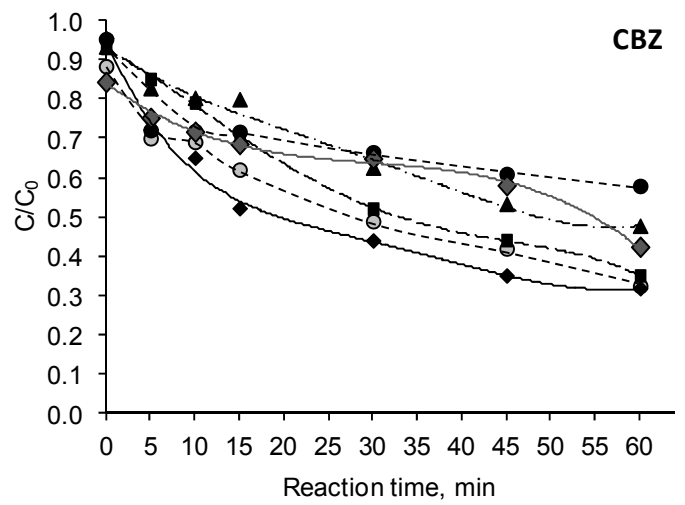

(c)

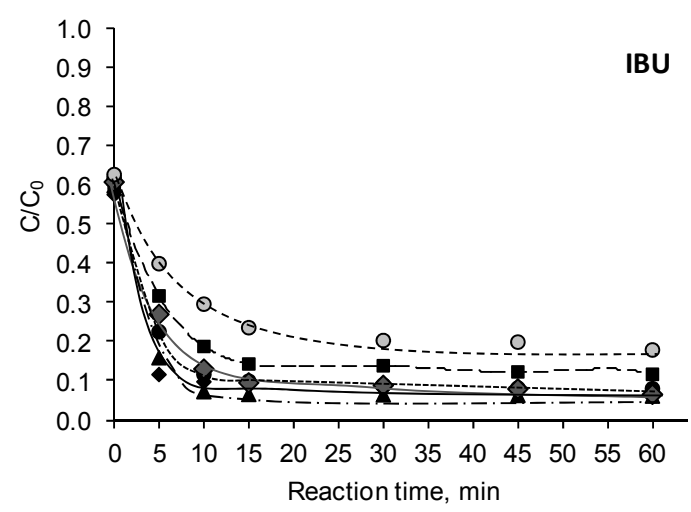

(b)

Figure 2. Influence of selected anions on the photocatalytic degradation of pharmaceuticals (a) diclofenac sodium salt (DCF); (b) ibuprofen sodium salt (IBU) and (c) carbamazepine (CBZ) present in water suspensions.

It was established that adding $\mathrm{Cl}^{-}, \mathrm{CO}_{3}^{2-}, \mathrm{HCO}_{3}^{-}$and $\mathrm{SO}_{4}^{2-}$ ions leads to a decrease of the DCF adsorption degree on the photocatalyst surface (Figure 2, reaction time $0 \mathrm{~min}$ ). The start of irradiation of the reaction mixture with UV resulted in the decrease of the drug removal to $80 \%, 34 \%, 80 \%$ and $65 \%$ subsequently after $60 \mathrm{~min}$ of irradiation, whereas in a solution without salts the removal exceeded $90 \%$ (Figure 2a). The mechanism of the process of heterogeneous photocatalysis assumes that the decomposition of compounds by reaction with $\mathrm{OH}^{\bullet}$ radicals occurs only when these compounds are adsorbed on the surface of the photocatalyst, or are directly in close proximity [24]. Competitive adsorption of inorganic ions on the surface of the photocatalyst preclude the adsorption of pharmaceutical compounds, leading to a reduction in the efficiency of their photochemical decomposition.

The inhibition of the oxidation and reduction of the pharmaceutical substance was caused mainly by a competitive adsorption of $\mathrm{Cl}^{-}, \mathrm{CO}_{3}^{2-}, \mathrm{HCO}_{3}^{-}$and $\mathrm{SO}_{4}^{2-}$ anions in the active centers on the catalyst surfaces. In the case where different ions react with positively charged electron holes, the intensity of the generation of hydroxyl radicals, which are mainly responsible for the distribution of contaminants, is lowered [25]. This affects the inhibition of the reaction of oxidation and/or reduction of compounds. For example, $\mathrm{Cl}^{-}$ions may react with "holes" of valence bands of $\mathrm{TiO}_{2}$ particles that leads to creating $\mathrm{Cl}^{\circ}, \mathrm{HClO}$ or $\mathrm{Cl}_{2}$ according to Equations (4)-(6) [26]. These radicals and compounds are well-known oxidants. Their ability to decompose organic compounds is closely connected with the chemical structure of the compounds and their functional groups (alkyl, alcohol, amide, acid, etc.) [27]. In the case of DCF, the formed oxidizing agents did not affect the increase in the decomposition of the pharmaceutical compound. This fact may be caused by the deprotonation of $\mathrm{HOCl}$ to yield $\mathrm{ClO}^{-}$ at a $\mathrm{pH}$ value above 6 . It should be recalled that the experiments were conducted at $\mathrm{pH} 7 . \mathrm{ClO}^{-}$ 
ions have in general a negligible reactivity, especially in the reaction with ionized forms of organic compounds [28].

$$
\begin{gathered}
\mathrm{h}_{\mathrm{pw}}^{+}+\mathrm{Cl}^{-} \rightarrow \mathrm{Cl}^{\bullet} \\
\mathrm{OH}^{\bullet}+\mathrm{Cl}^{\bullet} \rightarrow \mathrm{HClO} \\
\mathrm{Cl}^{\bullet}+\mathrm{Cl}^{\bullet} \rightarrow \mathrm{Cl}_{2}
\end{gathered}
$$

The decrease of efficiency of the process was far higher with the presence of such ions as $\mathrm{CO}_{3}^{2-}$, $\mathrm{HCO}_{3}^{-}$and $\mathrm{SO}_{4}^{2-}$ rather than $\mathrm{Cl}^{-}$. It is presumably connected with the higher value of the Van der Waals radius for carbonates, bicarbonates, sulphates in comparison to chlorides, which results in the higher efficiency to block active centres of a catalyst [29]. The decrease of efficiency of the photochemical degradation process of low- and high-molecular weight compounds was also proved in a wide range of other papers on this subject [30-35]. Moreover, the irradiation of the sulphate ions resulted in the generation of reactive sulphate anion radicals $\mathrm{SO}_{4}^{\cdot-}$ being able to decompose organic compounds [36]. The obtained research results show the superiority of the adsorption process of the $\mathrm{SO}_{4}^{2-}$ ions on the surface of $\mathrm{TiO}_{2}$ and the inhibition of the decomposition process of DCF over the drug oxidation through $\mathrm{SO}_{4}^{\bullet-}$ radicals. Among the investigated ions, only the $\mathrm{HPO}_{4}^{2-}$ ions did not influence the oxidation and reduction of DCF. The removal degree of that compound obtained in the considered irradiation time of $60 \mathrm{~min}$ of both suspensions with and without the addition of $\mathrm{HPO}_{4}^{2-}$ ions was very similar. The DCF concentration in the solution containing $\mathrm{HPO}_{4}^{2-}$ ions decreased by $80 \%$ after 60 min of UV irradiation, while in the solution without any inorganic additive the DCF concentration decreased by $50 \%$.

Different correlations were observed in case of IBU (Figure 2b). Both the addition of $\mathrm{Cl}^{-}, \mathrm{CO}_{3}^{2-}$, $\mathrm{HCO}_{3}^{-}, \mathrm{HPO}_{4}^{2-}$ as well as $\mathrm{SO}_{4}^{2-}$ increased the efficiency of the process and the obtained removal rates for this medication exceeded $92 \%$. Only in case of $\mathrm{CO}_{3}^{2-}$ ions did the removal rate for IBU reach $88 \%$. On the other hand, for the solution with no salt, the micropollutant removal rate reached only $82 \%$.

The increase in the intensity of the drug degradation for the solution containing $\mathrm{Cl}^{-}$ions was observed during the photocatalytic CBZ oxidation. This may be related to the generation of chlorinated oxidants, which supported the decomposition of the pharmaceutical by $\mathrm{OH}^{\bullet}$ radicals. The remaining anions inhibited the processes of oxidation and reduction of this micropollutant. Both ions $\mathrm{CO}_{3}^{2-}, \mathrm{HCO}_{3}^{-}, \mathrm{HPO}_{4}^{2-}$ as well as $\mathrm{SO}_{4}^{2-}$ have the ability to catch $\mathrm{OH}^{\bullet}$ radicals as a result of Reactions (7)-(10) [37]:

$$
\begin{gathered}
\mathrm{CO}_{3}^{2-}+\mathrm{OH}^{\bullet} \rightarrow \mathrm{CO}_{3}^{\bullet-}+\mathrm{OH}^{-} \\
\mathrm{HCO}_{3}^{-}+\mathrm{OH}^{\bullet} \rightarrow \mathrm{CO}_{3}^{\bullet-}+\mathrm{OH}^{-} \\
\mathrm{HPO}_{4}^{2-}+\mathrm{OH}^{\bullet} \rightarrow \mathrm{HPO}_{4}^{\bullet-}+\mathrm{OH}^{-} \\
\mathrm{SO}_{4}^{2-}+\mathrm{OH}^{\bullet} \rightarrow \mathrm{SO}_{4}^{\bullet-}+\mathrm{OH}^{-}
\end{gathered}
$$

The obtained radicals show the potential ability to decompose organic compounds, which was already mentioned in the case of $\mathrm{SO}_{4}^{--}$radicals, which enhance the degradation of drugs that contain a large number of nitrogen atoms [38] or carboxylic groups [39]. However, in the case of compounds which do not have carboxylic groups or contain fully oxidized nitrogen atoms, the presence of additional radicals may have an effect that is completely contrary. This was already confirmed in the case of CBZ oxidation and reduction.

The data analysis from the kinetics assessment of the photocatalysis occurring in the presence of ions $\mathrm{Cl}^{-}, \mathrm{CO}_{3}^{2-}, \mathrm{HCO}_{3}^{-}, \mathrm{HPO}_{4}^{2-}$ and $\mathrm{SO}_{4}^{2-}$ proved a significant difference between the rapidity of pharmaceutical compounds' degradation observed during the preliminary period of the process (up to $15 \mathrm{~min}$ ) and the rapidity of the process observed after the 15th minute of UV radiation (Table 3). These differences may result from a competitive sorption of inorganic compounds and by-products of pharmaceuticals decomposition on the surface of catalyst as well as the inhibition of the oxidation and/or reduction of pharmaceuticals. As an example, the mechanism of DCF decomposition in a 
solution with $\mathrm{NaHCO}_{3}$ runs very rapidly within the first 5 min of UV irradiation, with the half-life of the compound reaching $11.9 \mathrm{~min}$, and after $15 \mathrm{~min}$ of irradiation the oxidation process stops and the reaction rate constant decreases by almost three times. The reason behind this observation may be so called scavenging of hydroxyl radical by $\mathrm{HCO}_{3}^{-}$ions and producing carbonate radicals according to Reaction (8) or blockage of active centres of photocatalyst. Further irradiation of the solution results in re-acceleration of the oxidation and/or reduction of DCF, whereas the half-life of the compound decreases from 63.2 to $56.4 \mathrm{~min}$. However, it is not possible to explicitly indicate if any further decomposition of the medication is caused by the reaction with $\mathrm{OH}^{\bullet}$ radicals or $\mathrm{CO}_{3}^{\bullet-}$ radicals. A similar correlation was observed in case of the degradation of $\mathrm{CBZ}$ in the presence of $\mathrm{Na}_{2} \mathrm{SO}_{4} \cdot \mathrm{SO}_{4}^{2-}$ ions cause significant inhibition of the degradation process of the micropollutant due to their sorption in the active centres of semiconductor between 5 and $15 \mathrm{~min}$ of UV irradiation, whereas the half-life reaches $612.8 \mathrm{~min}$.

Table 3. Half-life of investigated pharmaceutical compounds during photocatalysis in the presence of selected anions.

\begin{tabular}{|c|c|c|c|c|c|}
\hline $\begin{array}{l}\text { Pharmaceutical } \\
\text { Compound }\end{array}$ & Ions & $\begin{array}{l}\text { Reaction Time, } \\
\text { (min) }\end{array}$ & $\begin{array}{c}\text { Reaction Rate } \\
\text { Constant } k,\left(\min ^{-1}\right)\end{array}$ & $R^{2}$ & $\begin{array}{l}\text { Half-Life } t_{\frac{1}{2}}, \\
\qquad(\min )\end{array}$ \\
\hline \multirow{13}{*}{ DCF } & \multirow{2}{*}{ - } & $0-15$ & 0.1395 & 0.89 & 8.4 \\
\hline & & $15-60$ & 0.0039 & 0.93 & 767.9 \\
\hline & \multirow{2}{*}{$\mathrm{Cl}^{-}$} & $0-15$ & 0.0808 & 0.98 & 11.6 \\
\hline & & $15-60$ & 0.0128 & 0.89 & 166.9 \\
\hline & \multirow{3}{*}{$\mathrm{CO}_{3}^{2-}$} & $0-15$ & 0.0209 & 0.87 & 38.0 \\
\hline & & $15-60$ & 0.0010 & 0.96 & 1077.8 \\
\hline & & $0-5$ & 0.0736 & 0.99 & 11.9 \\
\hline & \multirow{2}{*}{$\mathrm{HCO}_{3}^{-}$} & 5-15 & 0.0255 & 0.99 & 63.2 \\
\hline & & $15-60$ & 0.0330 & 0.88 & 56.4 \\
\hline & \multirow{2}{*}{$\mathrm{SO}_{4}^{2-}$} & $0-15$ & 0.0512 & 0.95 & 14.3 \\
\hline & & $15-60$ & 0.0130 & 0.96 & 119.9 \\
\hline & \multirow{2}{*}{$\mathrm{HPO}_{4}^{2-}$} & $0-15$ & 0.1375 & 0.94 & 8.1 \\
\hline & & $15-60$ & 0.0197 & 0.96 & 150.2 \\
\hline \multirow{12}{*}{ IBU } & \multirow{2}{*}{-} & $0-15$ & 0.0647 & 0.98 & 18.9 \\
\hline & & $15-60$ & 0.0170 & 0.93 & 127.2 \\
\hline & \multirow{2}{*}{$\mathrm{Cl}^{-}$} & $0-10$ & 0.1603 & 0.99 & 7.7 \\
\hline & & $10-60$ & 0.0101 & 0.84 & 293.1 \\
\hline & \multirow{2}{*}{$\mathrm{CO}_{3}^{2-}$} & $0-15$ & 0.0970 & 0.97 & 13.3 \\
\hline & & $15-60$ & 0.0147 & 0.95 & 178.8 \\
\hline & \multirow{2}{*}{$\mathrm{HCO}_{3}^{-}$} & $0-15$ & 0.1490 & 0.88 & 10.1 \\
\hline & & $15-60$ & 0.0043 & 0.98 & 797.0 \\
\hline & \multirow{2}{*}{$\mathrm{SO}_{4}^{2-}$} & $0-15$ & 0.1231 & 0.91 & 11.2 \\
\hline & & $15-60$ & 0.0147 & 0.93 & 206.1 \\
\hline & \multirow{2}{*}{$\mathrm{HPO}_{4}^{2-}$} & $0-15$ & 0.1261 & 0.97 & 10.3 \\
\hline & & $15-60$ & 0.0245 & 0.95 & 123.5 \\
\hline \multirow{11}{*}{ CBZ } & \multirow{3}{*}{$\mathrm{Cl}^{-}$} & $0-60$ & 0.0153 & 0.98 & 59.6 \\
\hline & & $0-15$ & 0.0384 & 0.97 & 16.07 \\
\hline & & $15-60$ & 0.0114 & 0.98 & 17.85 \\
\hline & \multirow{2}{*}{$\mathrm{CO}_{3}^{2-}$} & $0-60$ & 0.0165 & 0.99 & 47.4 \\
\hline & & $0-15$ & 0.0099 & 0.78 & 59.70 \\
\hline & \multirow{2}{*}{$\mathrm{HCO}_{3}^{-}$} & $15-60$ & 0.0114 & 0.97 & 52.90 \\
\hline & & $0-5$ & 0.0558 & 0.99 & 11.53 \\
\hline & \multirow{2}{*}{$\mathrm{SO}_{4}^{2-}$} & 5-15 & 0.0006 & 0.98 & 612.75 \\
\hline & & $15-60$ & 0.0049 & 0.99 & 87.30 \\
\hline & \multirow{2}{*}{$\mathrm{HPO}_{4}^{2-}$} & $0-15$ & 0.0134 & 0.94 & 37.40 \\
\hline & & $15-60$ & 0.0104 & 0.87 & 50.70 \\
\hline
\end{tabular}

\subsection{Influence of Inorganic Cations}

A further stage of the investigations assessed the influence of selected cations, i.e., $\mathrm{Al}^{3+}, \mathrm{Fe}^{3+}$, $\mathrm{Ca}^{2+}, \mathrm{Mg}^{2+}, \mathrm{NH}_{4}^{+}$, on the photochemical decomposition of micropollutants. Taking into consideration the fact that $\mathrm{Cl}^{-}$ions only negatively influenced the DCF degradation while stimulating the oxidation and reduction of the other pharmaceuticals, the chloride salts of the above mentioned cations were 
applied into the water suspensions of micropollutants. The obtained results were presented in Figure 3. The cations applied to the suspensions insignificantly influenced the adsorption rate of the micropollutants present in the water on the $\mathrm{TiO}_{2}$ surface. Only in the case of IBU did the presence of $\mathrm{Al}^{3+}$ and $\mathrm{Fe}^{3+}$ ions decrease the sorption efficiency with the drug decrease rate reaching $16 \%$ and $14 \%$ correspondingly.

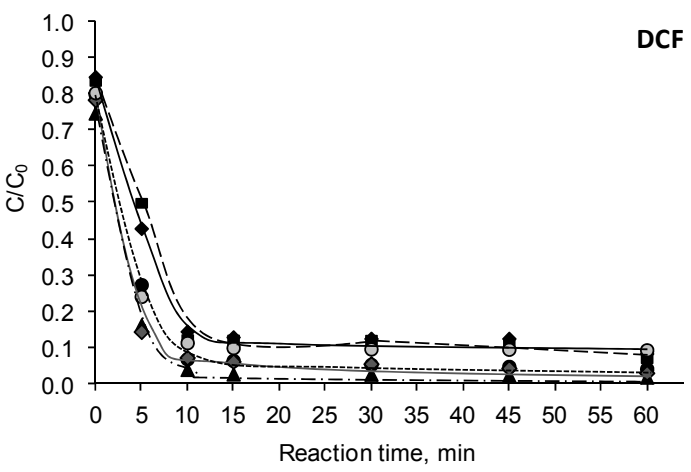

(a)

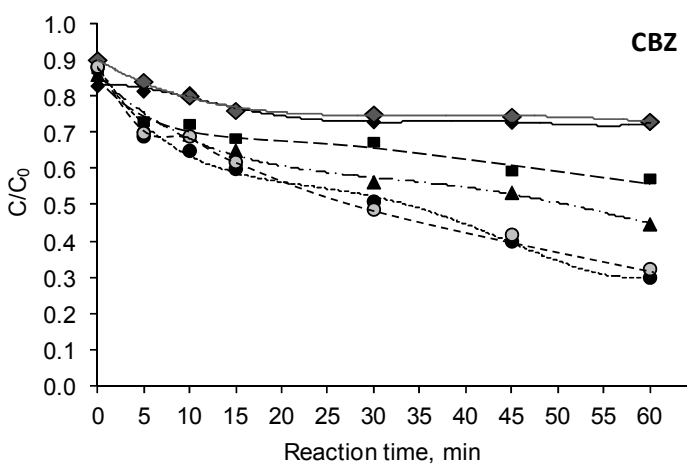

(c)

BZ

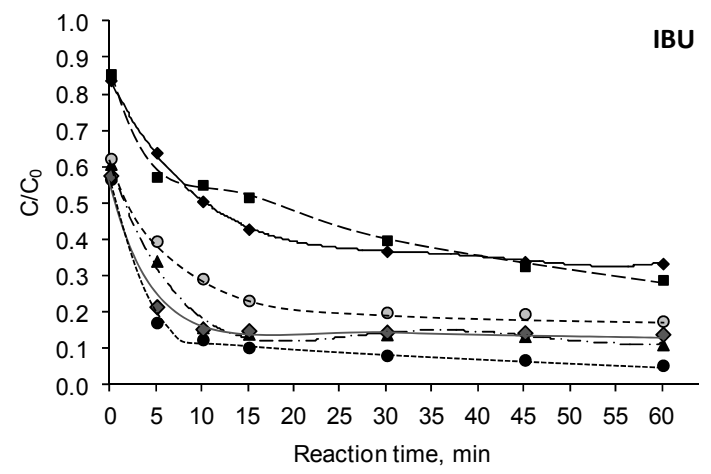

(b)

Figure 3. Influence of different cations on the photocatalytic degradation of pharmaceuticals (a) DCF;

(b) IBU and (c) CBZ present in water suspensions.

Additionally, it was determined that the presence of $\mathrm{Al}^{3+}$ and $\mathrm{Fe}^{3+}$ ions also decreases the efficiency of photochemical degradation of all investigated pharmaceutical compounds. In research [40] it was confirmed that $\mathrm{Al}^{3+}$ ions can precipitate on the surface of a photocatalyst and block its photoactivity. $\mathrm{Fe}^{3+}$ ions can also attract electrons emerging in the process of photoactivation of photocatalyst particles according to Equation (11) and lead to the decrease of the intensity of $\mathrm{OH}^{\bullet}$ radicals' generation.

$$
\mathrm{Fe}^{3+}+\mathrm{e}^{-} \rightarrow \mathrm{Fe}^{2+}
$$

In the case of the solution with $\mathrm{AlCl}_{3}$ the pharmaceuticals' removal rates obtained after $60 \mathrm{~min}$ of UV irradiation during photocatalysis reached correspondingly $91 \%$ for DCF, $66 \%$ for IBU and only $28 \%$ for CBZ. On the other hand, the micropollutants' removal rates in suspensions with $\mathrm{FeCl}_{3}$ obtained more than $92 \%$ for DCF, $71 \%$ for IBU and $43 \%$ for CBZ.

It was observed that the addition of $\mathrm{Ca}^{2+}, \mathrm{Mg}^{2+}, \mathrm{NH}_{4}^{+}$ions to suspensions with DCF and IBU facilitated their oxidation and/or reduction taking place during the photochemical process. The DCF removal rate reached the highest value exceeding $98 \%$ in the solution with $\mathrm{Ca}^{2+}$ cations. The most significant decrease for IBU concentration equal to $94 \%$ was obtained during the process conducted with the presence of $\mathrm{Mg}^{2+}$. Research presented in [41] proved that there is no influence of $\mathrm{Ca}^{2+}$, $\mathrm{Mg}^{2+}$ ions on the process of photocatalytic decomposition of inorganic compounds; thus, it may be 
deduced that the increase of IBU removal rate is a result of adding $\mathrm{Cl}^{-}$anions to the solution that were stimulating the decomposition of this pharmaceutical.

Conducted tests indicated that the decomposition of DCF in the process of heterogeneous photocatalysis was intensified in the presence of $\mathrm{Ca}^{2+}, \mathrm{Mg}^{2+}, \mathrm{NH}_{4}^{+}$cations, whereas $\mathrm{Al}^{3+}$ and $\mathrm{Fe}^{3+}$ cations inhibit the course of the oxidation and/or reduction reactions of the pharmaceutical. The influence of $\mathrm{Cl}^{-}, \mathrm{CO}_{3}^{2-}, \mathrm{HCO}_{3}^{-}$and $\mathrm{SO}_{4}^{2-}$ anions on the photochemical degradation of DCF was not as significant as in the case of anions.

In case of $\mathrm{CBZ}$ decomposition only, $\mathrm{Mg}^{2+}$ ions did not have a significant influence on the reaction course. Similarly to $\mathrm{Al}^{3+}$ and $\mathrm{Fe}^{3+}$ cations, the presence of $\mathrm{Ca}^{2+}$ and $\mathrm{NH}_{4}^{+}$ions decreased the removal rate of the compound which for the solution with $\mathrm{Ca}^{2+}$ equalled to $56 \%$ whereas for the process conducted with the presence of $\mathrm{NH}_{4}^{+}$it equalled only to $27 \%$. On the other hand, the process conducted with no inorganic compounds enabled to remove this micropollutant by $60 \%$.

Table 4 presents reaction rate constants and half-lives of pharmaceutical compounds determined for different time periods of heterogenic photocatalysis of suspensions containing selected cations.

Table 4. Half-life of investigated pharmaceutical compounds during photocatalysis in the presence of selected cations.

\begin{tabular}{|c|c|c|c|c|c|}
\hline $\begin{array}{l}\text { Pharmaceutical } \\
\text { Compound }\end{array}$ & Ions & $\begin{array}{l}\text { Reaction Time, } \\
\text { (min) }\end{array}$ & $\begin{array}{c}\text { Reaction Rate } \\
\text { Constant } k,\left(\min ^{-1}\right)\end{array}$ & $R^{2}$ & $\begin{array}{l}\text { Half-Life } t_{\frac{1}{2}}, \\
\quad(\min )\end{array}$ \\
\hline \multirow{11}{*}{ DCF } & \multirow{3}{*}{$\mathrm{Al}^{3+}$} & $0-10$ & 0.1760 & 0.98 & 4.5 \\
\hline & & $10-60$ & 0.0172 & 0.92 & 151.3 \\
\hline & & $0-10$ & 0.1904 & 0.93 & 3.8 \\
\hline & \multirow{2}{*}{$\mathrm{Fe}^{3+}$} & $10-30$ & 0.0013 & 0.96 & 2137.1 \\
\hline & & $30-60$ & 0.0539 & 0.89 & 50.8 \\
\hline & \multirow{2}{*}{$\mathrm{Ca}^{2+}$} & $0-15$ & 0.2241 & 0.94 & 5.5 \\
\hline & & $15-60$ & 0.0243 & 0.88 & 173.3 \\
\hline & \multirow{2}{*}{$\mathrm{Mg}^{2+}$} & $0-10$ & 0.2436 & 0.99 & 3.6 \\
\hline & & $10-60$ & 0.0171 & 0.92 & 197.9 \\
\hline & \multirow{2}{*}{$\mathrm{NH}_{4}^{+}$} & $0-10$ & 0.2365 & 0.94 & 4.7 \\
\hline & & $10-60$ & 0.0286 & 0.99 & 115.9 \\
\hline \multirow{10}{*}{ IBU } & \multirow{2}{*}{$\mathrm{Al}^{3+}$} & $0-15$ & 0.0447 & 0.99 & 20.0 \\
\hline & & $15-60$ & 0.0165 & 0.88 & 95.1 \\
\hline & \multirow{2}{*}{$\mathrm{Fe}^{3+}$} & $0-15$ & 0.0309 & 0.77 & 30.8 \\
\hline & & $15-60$ & 0.0385 & 0.98 & 35.9 \\
\hline & \multirow{2}{*}{$\mathrm{Ca}^{2+}$} & $0-15$ & 0.1023 & 0.94 & 12.3 \\
\hline & & $15-60$ & 0.0143 & 0.76 & 182.1 \\
\hline & \multirow{2}{*}{$\mathrm{Mg}^{2+}$} & $0-10$ & 0.1494 & 0.90 & 9.4 \\
\hline & & $10-60$ & 0.0267 & 0.93 & 106.0 \\
\hline & \multirow{2}{*}{$\mathrm{NH}_{4}^{+}$} & $0-10$ & 0.1307 & 0.92 & 10.3 \\
\hline & & $10-60$ & 0.0030 & 0.90 & 853.8 \\
\hline \multirow{8}{*}{ CBZ } & \multirow{2}{*}{$\mathrm{Al}^{3+}$} & $0-30$ & 0.0043 & 0.98 & 116.76 \\
\hline & & $30-60$ & 0.0002 & 0.97 & 1921.25 \\
\hline & \multirow{2}{*}{$\mathrm{Fe}^{3+}$} & $0-15$ & 0.0161 & 0.95 & 33.49 \\
\hline & & $15-60$ & 0.0042 & 0.98 & 89.85 \\
\hline & $\mathrm{Ca}^{2+}$ & $0-60$ & 0.0094 & 0.94 & 99.9 \\
\hline & $\mathrm{Mg}^{2+}$ & $0-60$ & 0.0160 & 0.97 & 57.6 \\
\hline & & $0-15$ & 0.0111 & 0.99 & 72.4 \\
\hline & $\mathrm{NH}_{4}$ & $15-60$ & 0.0026 & 0.97 & 371.9 \\
\hline
\end{tabular}

The shortest micropollutant half-lives were obtained for the processes conducted during the first 10 and 15 min of irradiation of the suspensions containing DCF. Thus, it can be deduced that the negative influence caused by adding the inorganic compounds occurred only during the further stages of the degradation processes of this micropollutant. It should be highlighted that the DCF oxidation and reduction processes carried out with $\mathrm{FeCl}_{3}$ undergo significant inhibition between 10th and 30th minute of the process. The half-live of the compound exceeds $2137 \mathrm{~min}$. The decomposition of IBU was the most rapid in the first $10 \mathrm{~min}$ of irradiation of the solution that included $\mathrm{MgCl}_{2}$. On the other hand, 
the longest CBZ half-life that reaches 1921.3 min was observed between the 30th and 60th minute of the process with the presence of $\mathrm{AlCl}_{3}$.

\subsection{Influence of Organic Substances}

The influence of high-molecule organic compounds present in the solution of the model effluent as a dry stock and casein peptone on the degradation of the pharmaceutical compounds was also assessed. Figure 4 presented a comparison of the decrease in pharmaceutical concentration during the UV irradiation of suspensions based on deionised water (Figure 4a) and model WWTP effluent. It was observed that the significant reduction of the micropollutant concentration already began during the sorption stage. It may be concluded that the pharmaceutical substances sorbed both on the surface of $\mathrm{TiO}_{2}$ particles and on the organic compounds present in the model WWTP effluent. It resulted in the decrease of the DCF concentration rate of $68 \%$, IBU of $77 \%$ and CBZ of more than $23 \%$. The start of the irradiation process enabled for more than $96 \%$ degradation of DCF in the first $10 \mathrm{~min}$ of the process, in which the half-life of the compound reached only $7.4 \mathrm{~min}$ (Table 5). The same situation was observed for IBU and its more than $96 \%$ decrease in concentration rate after $15 \mathrm{~min}$ of its photocatalytic oxidation, with its half-life not exceeding $18.3 \mathrm{~min}$. Further irradiation of the reaction mixture influenced the decrease of the reaction rate constant for DCF and IBU and the increase in half-life of the compounds to 253.7 and 110.6 min correspondingly.

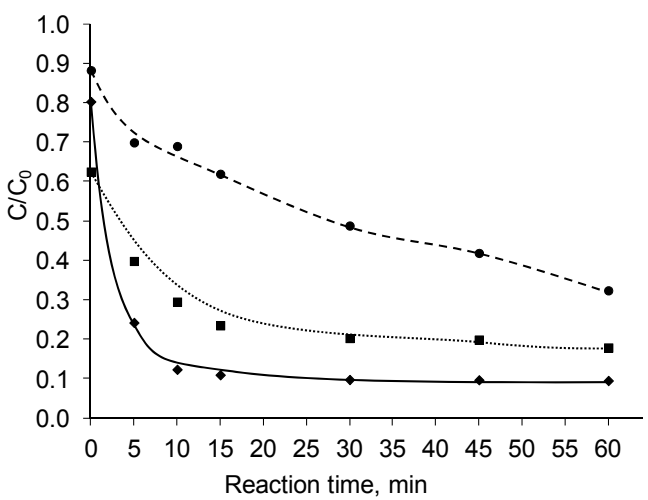

(a)

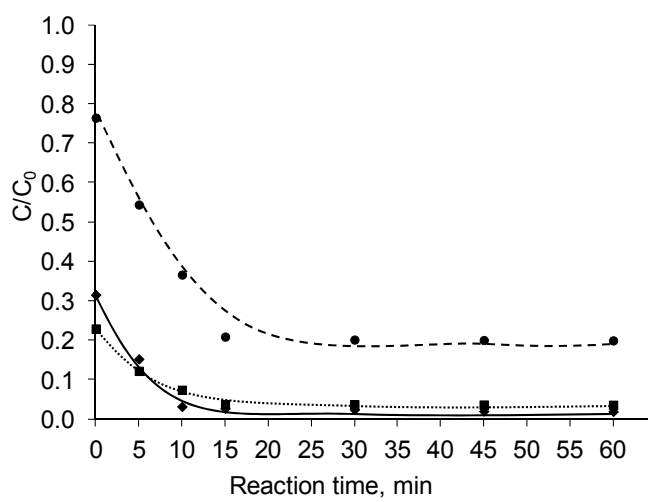

(b)

Figure 4. Degradation of pharmaceutical in (a) deionised water suspensions and (b) model WWTP effluent.

Table 5. Reaction rate constant and half-life of pharmaceutical compounds in the process of photocatalytic oxidation of the model effluent.

\begin{tabular}{ccccc}
\hline $\begin{array}{c}\text { Pharmaceutical } \\
\text { Compound }\end{array}$ & $\begin{array}{c}\text { Reaction } \\
\text { Time, (min) }\end{array}$ & $\begin{array}{c}\text { Reaction Rate } \\
\text { Constant } \boldsymbol{k},\left(\mathbf{m i n}^{-1}\right)\end{array}$ & $\boldsymbol{R}^{\mathbf{2}}$ & $\begin{array}{c}\text { Half-Life } \boldsymbol{t}_{\frac{1}{2}}, \\
(\mathbf{m i n})\end{array}$ \\
\hline \multirow{2}{*}{ DCF } & $0-10$ & 0.2303 & 0.96 & 7.4 \\
& $10-60$ & 0.0167 & 0.82 & 253.7 \\
\hline \multirow{2}{*}{ IBU } & $0-15$ & 0.1189 & 0.99 & 18.3 \\
& $15-60$ & 0.0360 & 0.99 & 110.6 \\
\hline \multirow{2}{*}{ CBZ } & $0-15$ & 0.0858 & 0.99 & 10.6 \\
& $15-60$ & 0.0029 & 0.78 & 782.7 \\
\hline
\end{tabular}

The decomposition of CBZ occurred more slowly. For the first 15 min of the process, the result of $k$ was almost three times lower than the reaction rate constant observed during the first stage of the DCF decomposition, whereas the concentration decrease of the pharmaceutical substance reached only $79 \%$. The established half-life was obtained from $10.6 \mathrm{~min}$ till the 15th minute of UV irradiation 
of the solution, and then it was prolonged up to $782.7 \mathrm{~min}$. It proves the significant inhibition of the oxidation and reduction processes of this micropollutant.

The increased efficiency of the micropollutants' decomposition in the model effluent in relation to the suspensions prepared with the use of deionized water may be a result of the presence of nitrite and nitrate that may indirectly constitute an additional source of $\mathrm{OH}^{\bullet}$ radicals [42-44] according to Reactions (12)-(14). Therefore, it can be deduced that the presence of other organic compounds including biogenic compounds facilitates the degradation process of pharmaceutical micropollutants. This deduction enables to anticipate a high efficiency in removal of these types of substances from the real effluent of wastewaters.

$$
\begin{aligned}
& \mathrm{NO}_{3}^{-} \stackrel{\text { hy }}{\rightarrow} \mathrm{O}^{\bullet-}+\mathrm{NO}_{2}^{\bullet} \\
& \mathrm{NO}_{2}^{-} \stackrel{\text { hy }}{\rightarrow} \mathrm{O}^{\bullet-}+\mathrm{NO}^{\bullet} \\
& \mathrm{O}^{\bullet-}+\mathrm{H}^{+} \stackrel{\text { hv }}{\rightarrow} \mathrm{OH}^{\bullet}
\end{aligned}
$$

\subsection{Toxicological Assessment of Treated Water Solution}

The last stage of the research investigated the toxicological influence of the post-reaction suspensions. The increase of toxic effect was observed for the start of the photochemical decomposition of pharmaceutical compounds in suspensions based on deionised water (Figure 5). It is correlated with the by-products from the micropollutant degradation processes that influence the decrease of the metabolic processes of the tested organisms. The slight increase of toxicity for DCF and IBU was observed only at the beginning of the process, i.e., up to $15 \mathrm{~min}$. Water of such characteristics is classified as non-toxic $[45,46]$. As a result of the further conduct of the process, a gradual decrease in water toxicity was observed, whereas negative values of bioluminescent inhibition of bacteria prove the existence of the stimulation of their metabolic processes. This shows probable evidence on a complete mineralization of micropollutants into $\mathrm{H}_{2} \mathrm{O}$ and $\mathrm{CO}_{2}$ or to the generation of products of their decomposition that influence the intensification of the oxidation process of luciferin into oxiluciferin that occurs in the organisms of the bioluminescent bacteria [47] and is responsible for generating radiation with a wavelength of about $490 \mathrm{~nm}$ [48].

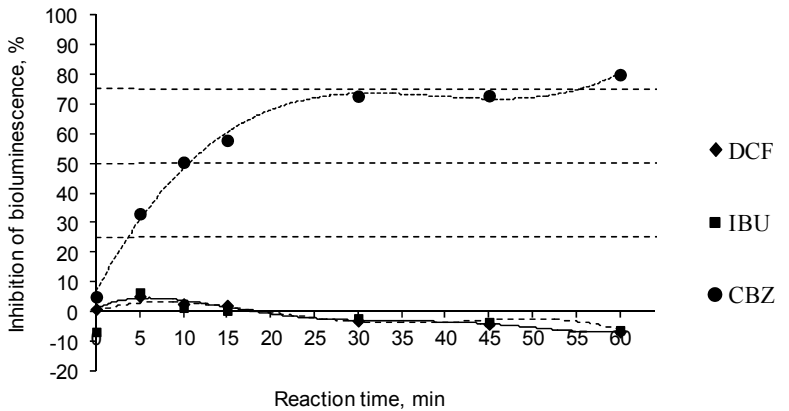

(a)

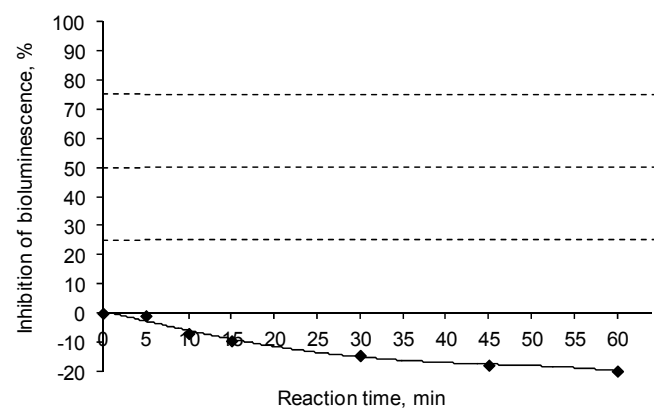

(b)

Figure 5. Change in toxicity of (a) deionised water suspensions and (b) model WWTP effluent. 
A significant increase in toxicity was observed for the irradiation of deionised water solution with CBZ. After $15 \mathrm{~min}$ of irradiation, the collected samples were classified as toxic, whereas after $60 \mathrm{~min}$ the post-reaction solution was characterised with high toxicity. The obtained results prove an incomplete decomposition of CBZ and production of oxidation by-products of this pharmaceutical substance that significantly deteriorates the quality of the treated water. Research presented in [49] show the possibility to produce a wide array of by-products of CBZ degradation during different processes of water treatment, among which the UV radiation is also enumerated. These compounds are characterised by higher biological activity that causes the increase in their toxic influence on other tested organisms [50].

No toxic response was observed during the irradiation process of the model effluent solution. The stimulation of the bacteria bioluminescence was observed in sample after 5 and $60 \mathrm{~min}$ of irradiation. It is connected with the high rate of micropollutant removal. Moreover, it may be concluded that by-products from the incomplete mineralization of pharmaceutical compounds underwent oxidation and/or reduction or adsorbed themselves on the substrates surfaces, which are a part of the model effluent, and composed complexes, for example: micropollutant-organic compound.

The generation of different oxidation by-products of DCF, IBU and CBZ was established during the GC-MS analysis of analyst present in water samples after their UV irradiation. The analysis was carried out for water suspension without the addition of organic and inorganic compounds. The by-products were identified based on the obtained mass spectrum. The possible degradation pathways of DCF ware illustrated in Figure 6. The decomposition of this pharmaceutical compound leads to the formation of nine by-products which were mainly present in samples after 5, 10 and $15 \mathrm{~min}$ of UV irradiation. Products of IBU decomposition ware shown on Figure 7. The CBZ decomposition by-products presented in Figure 8 were generated during the whole irradiation process.<smiles>Cc1ccccc1Nc1c(Cl)cccc1CC(=O)ON</smiles><smiles>Cc1ccccc1Nc1c(C)cccc1Cl</smiles>

Figure 6. Possible degradation pathway of $\mathbf{1}$ diclofenac sodium salt where $24^{\prime}$-hydroxydiclofenac, 3 1-(2,6-dichlorophenyl)-2-indolinone, 4 2-hydroxyphenylacetic acid, 5 2-dichlorodiphenylamine, $6 \mathrm{~N}$-(2,6-dichlorophenyl)-2-aminotoluene, 7 2-indolinone, 8 2,3-dihydroxyphenylacetic acid, 9 2,6-dichloroaniline and 10 4-amino-3,5-dichlorophenol. 
<smiles>CC(C)Cc1ccc(C(C)C(=O)ON)cc1</smiles><smiles>CCc1ccc(C=O)cc1CC(C)(C)Cc1ccc(C(C)C(C)(C)O)cc1CC(C)(C)O</smiles>

Figure 7. Possible degradation pathway of 1 ibuprofen sodium salt where 2 1-hydroxyibuprofen 3 2-hydroxy-2-[4-(2-methylpropyl)phenyl]propionic acid, 4 2-(4-isopropylcarbonylphenyl)propanoic acid, 5 1-(4-isobutylphenyl)-1-ethanol, 6 2-hydroxyibuprofen, 7 1-[4-(2-methylpropyl)phenyl] ethanone, 8 2-(4-formylphenyl)propanoic acid, 9 1-(4-isobutylphenyl)-1-ethanone, 101-ethyl-4-(2-hydroxy)isobutyl benzene, 11 4-(1-hydroxy-2-methylpropyl)acetophenone, 12 4-ethylbenzaldehyde, 13 1-(4-acetylphenyl)-2-methyl-1-propanone and 14 4-acetylbenzoic acid.

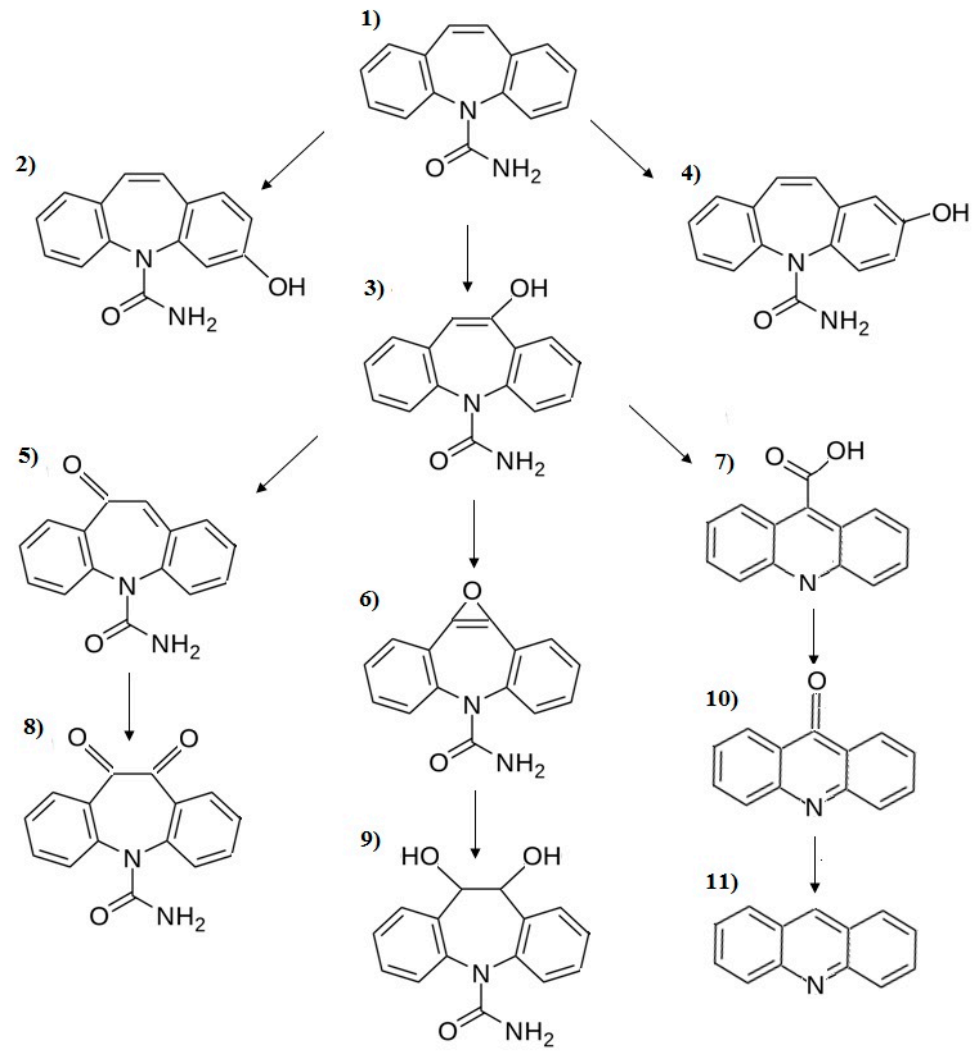

Figure 8. Possible degradation pathway of 1 carbamazepine where $\mathbf{2}$ 3-hydroxycarbamazepine, 3 10,11-dihydro-10-hydroxycarbamazepine, 4 2-hydroxycarbamazepine, 5 oxcarbazepine, 6 carbamazepine 10,11-epoxide, 7 acridine-9 carboxylic acid, 8 diketo-oxcarbazepine, 9 dihydrocarbamazepine-10,11-trans-diol, 10 acridine and $\mathbf{1 1}$ acridine. 


\section{Conclusions}

On the basis of the conducted investigations on the assessment of the decomposition rate of DCF, IBU and CBZ in the process of photocatalytic oxidation in the presence of inorganic compounds, it was concluded that the efficiency of micropollutants' decomposition strictly depends on the type of pharmaceutical compound as well as on the inorganic ions themselves. In DCF suspensions, a significantly decrease in the compound was observed in the presence of $\mathrm{Cl}^{-}, \mathrm{CO}_{3}^{2-}, \mathrm{HCO}_{3}^{-}$and $\mathrm{SO}_{4}^{2-}$ ions. The decomposition of CBZ was most effective in deionised water with $\mathrm{Cl}^{-}$, whereas the presence of $\mathrm{CO}_{3}^{2-}, \mathrm{HCO}_{3}^{-}, \mathrm{HPO}_{4}^{2-}$ and $\mathrm{SO}_{4}^{2-}$ inhibited the reaction course of the compound decomposition in an explicit way. A contrary relation was observed for IBU. In this case, all anions facilitated the process of its photochemical oxidation and/or reduction. The presence of $\mathrm{Al}^{3+}$ and $\mathrm{Fe}^{3+}$ cations affected the decrease of the process efficiency for all investigated pharmaceutical compounds. For DCF and IBU in suspensions containing $\mathrm{Ca}^{2+}, \mathrm{Mg}^{2+}$ and $\mathrm{NH}_{4}{ }^{+}$, the increase of the reaction rate constant of compounds' decomposition was observed in comparison to a solution with no inorganic compounds added. The highest removal rate of micropollutants was observed for the model effluent that exceeded $96 \%$ for DCF and IBU and reached $79 \%$ for CBZ. The presence of inorganic compounds with high molecular weight catalyses the degradation process of pharmaceutical compounds and constitutes an additional sorbent that is able to significantly reduce their concentration. The toxicological analysis conducted in the deionised water showed generation of by-products of the oxidation and/or reduction of pharmaceutical micropollutants that deteriorate the quality of the treated aqueous streams. This was explicitly visible for the oxidation of a solution with CBZ which characterised itself with high toxicity after 60 min of the process. The presence of organic compounds affects the decrease of water toxicity, which is visible in the stimulation of metabolic processes of bacterium Alivibrio fischeri. The gas chromatography-mass spectrometry (GC-MS) analysis allowed for the estimation of the possible photocatalytic degradation pathways of the examined pharmaceutical compounds.

Acknowledgments: This research was supported by a grant (code BKM/53/RIE4/2015) for young scientists from the Faculty of Energy and Environmental Engineering, Silesian University of Technology and the frame of the National Science Center of Poland project based on decision No. DEC-2013/11/B/ST8/04391.

Author Contributions: Edyta Kudlek developed the methodology and conducted the work under the supervision and review of Mariusz Dudziak and Jolanta Bohdziewicz.

Conflicts of Interest: The authors declare no conflict of interest.

\section{References}

1. Luo, Y.; Guo, W.; Ngo, H.H.; Nghiem, L.D.; Hai, F.I.; Zhang, J.; Liang, S.; Wang, X.C. A review on the occurrence of micropollutants in the aquatic environment and their fate and removal during wastewater treatment. Sci. Total Environ. 2014, 473-474, 619-641. [CrossRef] [PubMed]

2. Santos, L.H.M.L.M.; Araújo, A.N.; Fachini, A.; Pena, A.; Delerue-Matos, C.; Montenegro, M.C.B.S.M. Ecotoxicological aspects related to the presence of pharmaceuticals in the aquatic environment. J. Hazard. Mater. 2010, 175, 45-95. [CrossRef] [PubMed]

3. Oller, I.; Malato, S.; Sánchez-Pérez, J.A. Combination of advanced oxidation processes and biological treatments for wastewater decontamination-A review. Sci. Total Environ. 2011, 409, 4141-4166. [CrossRef] [PubMed]

4. Gros, M.; Petrović, M.; Ginebreda, A.; Barceló, D. Removal of pharmaceuticals during wastewater treatment and environmental risk assessment using hazard indexes. Environ. Int. 2010, 36, 15-26. [CrossRef] [PubMed]

5. Jelic, A.; Gros, M.; Ginebreda, A.; Cespedes-Sánchez, R.; Ventura, F.; Petrovic, M.; Barcelo, D. Occurrence, partition and removal of pharmaceuticals in sewage water and sludge during wastewater treatment. Water Res. 2011, 45, 1165-1176. [CrossRef] [PubMed]

6. De Witte, B.; van Langenhove, H.; Demeestere, K.; Dewulf, J. Advanced oxidation of pharmaceuticals: Chemical analysis and biological assessment of degradation products. Crit. Rev. Environ. Sci. Technol. 2011, 41, 215-242. [CrossRef] 
7. Liang, R.; Hu, A.; Li, W.; Zhou, N. Enhanced degradation of persistent pharmaceuticals found in wastewater treatment effluents using $\mathrm{TiO}_{2}$ nanobelt photocatalysts. J. Nanopart. Res. 2013, 15, 1990. [CrossRef]

8. Bohdziewicz, J.; Kudlek, E.; Dudziak, M. Influence of the catalyst type $\left(\mathrm{TiO}_{2}\right.$ and $\left.\mathrm{ZnO}\right)$ on the photocatalytic oxidation of pharmaceuticals in the aquatic environment. Desalin. Water Treat. 2016, 57, 1552-1563. [CrossRef]

9. Czech, B.; Buda, W. Photocatalytic treatment of pharmaceutical wastewater using new multiwall-carbon nanotubes $/ \mathrm{TiO}_{2} / \mathrm{SiO}_{2}$ nanocomposites. Environ. Res. 2015, 137, 176-184. [CrossRef] [PubMed]

10. Hu, A.; Zhang, X.; Oakes, K.D.; Peng, P.; Zhou, Y.N.; Servos, M.R. Hydrothermal growth of free standing $\mathrm{TiO}_{2}$ nanowire membranes for photocatalytic degradation of pharmaceuticals. J. Hazard. Mater. 2011, 189, 278-285. [CrossRef] [PubMed]

11. Gaya, U.I.; Abdullah, A.H. Heterogeneous photocatalytic degradation of organic contaminants over titanium dioxide: A review of fundamentals, progress and problems. J. Photochem. Photobiol. C Photochem. Rev. 2008, 9, 1-12. [CrossRef]

12. Chládková, B.; Evgenidou, E.; Kvítek, L.; Panáček, A.; Zbořil, R.; Kovář, P.; Lambropoulou, D. Adsorption and photocatalysis of nanocrystalline $\mathrm{TiO}_{2}$ particles for Reactive Red 195 removal: Effect of humic acids, anions and scavengers. Environ. Sci. Pollut. Res. 2015, 22, 16514-16524. [CrossRef] [PubMed]

13. Zhang, J.; Wang, X.; Wang, J.; Wang, J.; Ji, Z. Effect of sulfate ions on the crystallization and photocatalytic activity of $\mathrm{TiO}_{2}$ /diatomite composite photocatalyst. Chem. Phys. Lett. 2016, 643, 53-60. [CrossRef]

14. Li, S.-W.; Lin, A.Y. Increased acute toxicity to fish caused by pharmaceuticals in hospital effluents in a pharmaceutical mixture and after solar irradiation. Chemosphere 2015, 139, 190-196. [CrossRef] [PubMed]

15. Villain, J.; Minguez, L.; Halm-Lemeille, M.-P.; Durrieu, G.; Bureau, R. Acute toxicities of pharmaceuticals toward green algae. mode of action, biopharmaceutical drug disposition classification system and quantile regression models. Ecotoxicol. Environ. Saf. 2016, 124, 337-343. [CrossRef] [PubMed]

16. Libralato, G.; Prato, E.; Migliore, L.; Cicero, A.M.; Manfra, L. A review of toxicity testing protocols and endpoints with Artemia spp. Ecol. Indic. 2016, 69, 35-49. [CrossRef]

17. Dolezalova, J.; Rumlova, L. A new biological test of water toxicity-yeast Saccharomyces cerevisiae conductometric test. Environ. Toxicol. Pharmacol. 2014, 38, 977-981. [CrossRef] [PubMed]

18. Czech, B.; Jośko, I.; Oleszczuk, P. Ecotoxicological evaluation of selected pharmaceuticals to Vibrio fischeri and Daphnia magna before and after photooxidation process. Ecotoxicol. Environ. Saf. 2014, 104, 247-253. [CrossRef] [PubMed]

19. Yu, X.; Zuo, J.; Tang, X.; Li, R.; Li, Z.; Zhang, F. Toxicity evaluation of pharmaceutical wastewaters using the alga Scenedesmus obliquus and the bacterium Vibrio fischeri. J. Hazard. Mater. 2014, 266, 68-74. [CrossRef] [PubMed]

20. Lopez-Roldan, R.; Kazlauskaite, L.; Ribo, J.; Riva, M.C.; González, S.; Cortina, J.L. Evaluation of an automated luminescent bacteria assay for in situ aquatic toxicity determination. Sci. Total Environ. 2012, 440, 307-313. [CrossRef] [PubMed]

21. Hu, A.; Zhang, X.; Luong, D.; Oakes, K.D.; Servos, M.R.; Liang, R.; Kurdi, S.; Peng, P.; Zhou, Y. Adsorption and photocatalytic degradation kinetics of pharmaceuticals by $\mathrm{TiO}_{2}$ nanowires during water treatment. Waste Biomass Valoriz. 2012, 3, 443-449. [CrossRef]

22. Chiou, C.-H.; Wu, C.-Y.; Juang, R.-S. Photocatalytic degradation of phenol and $m$-nitrophenol using irradiated $\mathrm{TiO}_{2}$ in aqueous solutions. Sep. Purif. Technol. 2008, 62, 559-564. [CrossRef]

23. Holmberg, J.P.; Ahlberg, E.; Bergenholtz, J.; Hassellöv, M.; Abbas, Z. Surface charge and interfacial potential of titanium dioxide nanoparticles: Experimental and theoretical investigations. J. Colloid Interface Sci. 2013, 407, 168-176. [CrossRef] [PubMed]

24. Augugliaro, V.; Bellardita, M.; Loddo, V.; Palmisano, G.; Palmisano, L.; Yurdaka, S. Overview on oxidation mechanisms of organic compounds by $\mathrm{TiO}_{2}$ in heterogeneous photocatalysis. J. Photochem. Photobiol. C Photochem. Rev. 2012, 13, 224-245. [CrossRef]

25. Surolia, K.P.; Tayade, R.J.; Jasra, R.V. Effect of anions on the photocatalytic activity of Fe(III) salts impregnated $\mathrm{TiO}_{2}$. Ind. Eng. Chem. Res. 2007, 46, 6196-6203. [CrossRef]

26. Boxall, C.; Kelsall, G.H. Photoelectrophoresis of colloidal semiconductors. Part 1. The technique and its applications. Faraday Trans. 1991, 87, 3537-3545. [CrossRef] 
27. Deborde, M.; von Gunten, U. Reactions of chlorine with inorganic and organic compounds during water treatment-Kinetics and mechanisms: A critical review. Water Res. 2008, 42, 13-51. [CrossRef] [PubMed]

28. Soufan, M.; Deborde, M.; Legube, B. Aqueous chlorination of diclofenac: Kinetic study and transformation products identification. Water Res. 2012, 46, 3377-3386. [CrossRef] [PubMed]

29. Liqiang, J.; Xiaoarn, S.; Naifu, X.; Baiqi, W.; Weimain, C.; Honggang, F. The preparation and characterisation of La doped $\mathrm{TiO}_{2}$ nanoparticles and their photocatalytic activity. J. Solid State Chem. 2004, 177, 3375-3382. [CrossRef]

30. Al-Rasheed, R.; Cardin, D.J. Photocatalytic, degradation of humic acid in saline waters. Part 1. Artificial seawater: Influence of $\mathrm{TiO}_{2}$, temperature, $\mathrm{pH}$, and air-flow. Chemosphere 2003, 51, 925-933. [CrossRef]

31. Yawalkar, A.A.; Bhatkhande, D.S.; Pangarkar, V.G.; Beenackers, A.A.C.M. Solar-assisted photochemical and photocatalytic degradation of Phenol. J. Chem. Technol. Biotechnol. 2001, 76, 363-370. [CrossRef]

32. Bhatkhande, D.S.; Pangarkar, V.G.; Beenackers, A.A.C.M. Photocatalytic degradation of nitrobenzene using titanium dioxide and concentrated solar radiation: Chemical effects and scaleup. Water Res. 2003, 37, 1223-1230. [CrossRef]

33. Ajmera, A.A.; Sawant, S.B.; Pangarkar, V.G.; Beenackers, A.A.C.M. Solar-assisted photocatalytic degradation of benzoic acid using titanium dioxide as a photocatalyst. Chem. Eng. Technol. 2002, 25, 173-180. [CrossRef]

34. Zhang, Y.; Ji, X.; Li, H.; Chen, J.; Wang, Y. Investigation of photocatalytic activity of nano-sized $\mathrm{TiO}_{2}$ with the presence of various inorganic anions. J. Nanosci. Nanotechnol. 2009, 9, 3639-3643. [CrossRef] [PubMed]

35. Bouanimba, N.; Laid, N.; Zouaghi, R.; Sehili, T. Effect of $\mathrm{pH}$ and inorganic salts on the photocatalytic decolorization of methyl orange in the presence of $\mathrm{TiO}_{2} \mathrm{P} 25$ and PC500. Desalin. Water Treat. 2015, 53, 951-963.

36. Nfodzo, P.; Choi, H. sulfate radicals destroy pharmaceuticals and personal care products. Environ. Eng. Sci. 2011, 28, 605-609. [CrossRef]

37. Zhu, R.S.; Tian, F.; Dong, W.Y.; Ouyang, F.; Zhang, L.L. Effects of inorganic anions on $\mathrm{TiO}_{2}$ photocatalytic reduction of $\mathrm{BrO}_{3}$. Adv. Mater. Res. 2012, 428, 69-72. [CrossRef]

38. Ji, Y.; Ferronato, C.; Salvador, A.; Yanga, X.; Chovelon, J.-M. Degradation of ciprofloxacin and sulfamethoxazole by ferrous-activated persulfate: Implications for remediation of groundwater contaminated by antibiotics. Sci. Total Environ. 2014, 472, 800-808. [CrossRef] [PubMed]

39. Hori, H.; Yamamoto, A.; Hayakawa, E.; Taniyasu, S.; Yamashita, N.; Kutsuna, S. Efficient decomposition of environmentally persistent perfluorocarboxylic acids by use of persulfate as a photochemical oxidant. Environ. Sci. Technol. 2005, 39, 2383-2388. [CrossRef] [PubMed]

40. Egerton, T.A. The influence of surface alumina and silica on the photocatalytic degradation of organic pollutants. Catalysts 2013, 3, 338-362. [CrossRef]

41. Zhao, C.; Pelaez, M.; Dionysiou, D.D.; Pillai, S.C.; Byrne, J.A.; O'Shea, K.E. UV and visible light activated TiO photocatalysis of 6-hydroxymethyl uracil, a model compound for the potent cyanotoxin cylindrospermopsin. Catal. Today 2014, 224, 70-76. [CrossRef]

42. Goldstein, S.; Rabani, J. Mechanism of nitrite formation by nitrate photolysis in aqueous solutions: The role of peroxynitrite, nitrogen dioxide, and hydroxyl radical. J. Am. Chem. Soc. 2007, 129, 10597-10601. [CrossRef] [PubMed]

43. Mack, J.; Bolton, J.R. Photochemistry of nitrite and nitrate in aqueous solution: A review. J. Photochem. Photobiol. A Chem. 1999, 128, 1-13. [CrossRef]

44. Bianco, A.; Passananti, M.; Perroux, H.; Voyard, G.; Mouchel-Vallon, C.; Chaumerliac, N.; Mailhot, G.; Deguillaume, L.; Brigante, M. A better understanding of hydroxyl radical photochemical sources in cloud waters collected at the puy de Dôme station-Experimental versus modelled formation rates. Atmos. Chem. Phys. 2015, 15, 9191-9202. [CrossRef]

45. Werle, S.; Dudziak, M. Evaluation of tixicity of sawage sludge and gasification waste-products. Chem. Rev. 2013, 92, 1350-1353.

46. Hsieh, C.-Y.; Meng-Hsiun, T.; Ryan, D.K.; Pancorbo, O.C. Toxicity of the 13 priority pollutant metals to Vibrio fischeri in the Microtox ${ }^{\circledR}$ chronic toxicity test. Sci. Total Environ. 2004, 320, 37-50. [CrossRef]

47. Miyashiro, T.; Ruby, E.G. Shedding light on bioluminescence regulation in Vibrio fischeri. Mol. Microbiol. 2012, 84, 795-806. [CrossRef] [PubMed] 
48. Yaser, N.A.; Abdullah, M.F.F.; Aris, A.M.; Zainudin, I.I. Isolation and identification of bioluminescent bacteria in squid and water of Malaysia. Int. J. Adv. Agric. Environ. Eng. 2014, 1, 225-228.

49. Li, Z.; Fenet, H.; Gomez, E.; Chiron, S. Transformation of the antiepileptic drug oxcarbazepine upon different water disinfection processes. Water Res. 2011, 45, 1587-1596. [CrossRef] [PubMed]

50. Heye, K.; Becker, D.; Lütke Eversloh, C.; Durmaz, V.; Ternes, T.A.; Oetken, M.; Oehlmann, J. Effects of carbamazepine and two of its metabolites on the non-biting midge. Chironomus riparius in a sediment full life cycle toxicity test. Water Res. 2016, 98, 19-27.

(C) 2016 by the authors; licensee MDPI, Basel, Switzerland. This article is an open access article distributed under the terms and conditions of the Creative Commons Attribution (CC-BY) license (http:/ / creativecommons.org/licenses/by/4.0/). 